\title{
Effect of high temperature on immobilization of heavy metals in concrete with an addition of galvanic sludge
}

\author{
A. Król \\ Faculty of Environmental Engineering, \\ Opole University of Technology, Poland
}

\begin{abstract}
The paper presents the results of research devoted to the stability of concretes based on various cements, which contain added galvanic sludge content in the circumstances of various temperature levels $\left(200^{\circ} \mathrm{C}, 400^{\circ} \mathrm{C}, 600^{\circ} \mathrm{C}\right)$. The mechanical properties of stabilizing concretes under various temperatures are presented. The particular focus was placed on the immobilization of heavy metals following the process of roasting concrete specimens under high temperatures.

Keywords: concrete, leaching, heavy metals, high temperature conditions, galvanic sludge.
\end{abstract}

\section{Introduction}

The neutralization of waste containing heavy metals constitutes a complex task since the selection of an appropriate method of neutralization should secure the irreversible deactivation of heavy metals. The neutralization of the waste applies the conventional methods (most frequently combustion). However, the application of such methods results in the generation of post-processing waste (e.g. fly ash or slag), which still contains heavy metals.

Galvanic sewage sludge originating from the plants in the branch of metal surface work constitutes, in the majority of cases, quite hazardous waste. As a result of huge heavy metals content its disposal is difficult. One of the methods for neutralizing this type of sludge consists of solidifying it in materials based on mineral binders. 
Stabilization of waste in cement composites has become the subject of numerous studies and examinations. The application of this method enables permanent solidification of heavy metals in the structure of concrete due to the reactions of hydratation and the products resulting.

Cements that are commonly used as stated in [1] are applied for the processes of permanent solidifying of hazardous waste with heavy metals content. This applies a combination of two processes: solidification and stabilization. Solidification with the aid of cement and related materials provides for the change in physical properties of this waste. The result of these processes takes the form of waste material with considerably limited (predominantly low) liquid phase content, which is mostly responsible for the carriage of harmful substances into the environment. Stabilization is the result of chemical changes in contaminants and their environment that cause the contaminants to be less mobile or less toxic. These pollutants (including heavy metal compounds) as a result of the processes of sorption, substitution and encapsulation are transformed into insoluble form, which practically prevents its leaching into water or soil [2]. Solidification/stabilization of waste with the aid of cement materials is associated with the process of hydration. This results in a security of gaining stable and insoluble forms, such as C-S-H-phase, calcium aluminate and sulfoaluminate hydrates, which play a very relevant role in the immobilization of heavy metals.

The heavy metals release into the environment from concrete matrices solidifying waste is associated with the particular cement or binder applied and the technology of concrete production. Such factors have the fundamental effect on the durability and porosity of the concrete [2]. The leaching of the heavy metals from the concrete is also affected by the time taken for the water extracts to be taken [3]. The leaching of the heavy metals may also be affected by the high temperature of the environment affecting the performance of the concrete. The detrimental effect of the high temperature on the concrete is associated with its destructive effect reflected in the formation of cracks ultimately leading to its destruction [4].

This paper presents the results of the analysis of heavy metal leaching from concretes including hazardous waste under the influence of high temperatures $\left(200^{\circ} \mathrm{C}, 400^{\circ} \mathrm{C}, 600^{\circ} \mathrm{C}\right)$.

\section{Materials and methods}

The process of solidification involved the sludge from the treatment of galvanic sewage, which were classified with code number 190813* "slurry containing hazardous materials from other than biological treatment of industrial sewage" in accordance with [5]. Chemical composition and heavy metals content of the sludge used in this experiment are summarized in Table 1. Besides, Table 1 gives the concentration of heavy metals in water extracts from this sludge and permissible content of heavy metals in extract for the case of storage of waste classified in the group "neutral" and "other than hazardous and neutral waste" in accordance with [6]. The water extracts from this sludge were tested in 
accordance with procedure included in EN 12457-1-4:2002 [7]. This procedure is also referred to by Council Decision 2003/33/EC [6] in classifying waste admitted to waste dumps.

Table 1: Chemical composition and heavy metals content in galvanic sewage sludge and water extracts from sludge.

\begin{tabular}{|c|c||c|c|c|c|c|}
\hline \multicolumn{2}{|c||}{$\begin{array}{c}\text { Main components, } \\
\% \text { of mass }\end{array}$} & \multicolumn{3}{c|}{$\begin{array}{c}\text { Heavy metals, mg/kg of solid } \\
\text { mass }\end{array}$} & \multicolumn{2}{c|}{$\begin{array}{r}\text { Permissible content in } \\
\text { water extracts in } \\
\text { accordance with [6], } \\
\text { mg/kg of solid mass }\end{array}$} \\
\hline $\begin{array}{c}\text { Loss on } \\
\text { ignition }\end{array}$ & 41.35 & $\begin{array}{c}\text { Heavy } \\
\text { metal }\end{array}$ & $\begin{array}{c}\text { Solid } \\
\text { mass } \\
\text { extracts }\end{array}$ & $\begin{array}{c}\text { Water } \\
\text { weutral } \\
\text { waste }\end{array}$ & $\begin{array}{c}\text { Other than } \\
\text { hazardous and } \\
\text { neutral waste }\end{array}$ \\
\hline $\mathrm{SiO}_{2}$ & 3.01 & $\mathrm{Cr}$ & 270100.7 & 3.04 & 0.5 & 10.0 \\
\hline $\mathrm{Al}_{2} \mathrm{O}_{3}$ & 0.83 & $\mathrm{Zn}$ & 1441.1 & 4.44 & 4.0 & 50.0 \\
\hline $\mathrm{Fe}_{2} \mathrm{O}_{3}$ & 1.08 & $\mathrm{Ni}$ & 12789.6 & 8.86 & 0.4 & 10.0 \\
\hline $\mathrm{CaO}^{2}$ & 0.11 & $\mathrm{Cu}$ & 38443.5 & 0.48 & 2 & 50.0 \\
\hline $\mathrm{MgO}^{2}$ & 0.01 & $\mathrm{Cd}$ & 1133.5 & 0.71 & 0.04 & 1.0 \\
\hline $\mathrm{SO}_{3}$ & 5.85 & $\mathrm{~Pb}$ & 545.8 & 0.017 & 0.5 & 10.0 \\
\hline $\mathrm{Na}_{2} \mathrm{O}$ & 3.11 & $\mathrm{As}$ & 20.5 & 0.015 & 0.5 & 2.0 \\
\hline $\mathrm{K}_{2} \mathrm{O}$ & 0.18 & $\mathrm{Hg}$ & 31.8 & 0.0053 & 0.01 & 0.2 \\
\hline
\end{tabular}

It could be stressed here that galvanic sewage sludge could not be included into the group of neutral waste since heavy metal content (chromium, zinc, nickel and cadmium) considerably exceeds concentration levels of heavy metals content in water extracts (see Table 1) for waste stored in neutral waste dumps [6].

Concretes based on Portland cement CEM I 32.5 R and fly ash Portland cement CEM II/B-V 32.5 R-HSR constituted the matrices for the solidifying of galvanic sludge. This sludge was added in the amount equal to $10 \%$ of solid mass of cement content in concrete mix. Concrete including $300 \mathrm{~kg} / \mathrm{m}^{3}$ of cement, while $\mathrm{w} / \mathrm{c}=0.6$ (water/cement ratio) were prepared in accordance with [8]. The concrete mix including sludge was formed into cubes $10 \times 10 \times 10 \mathrm{~cm}$.

After storing for 90 days in laboratory conditions [9] the concrete specimens were subjected to drying to reach solid mass consistence in a dryer at the temperature of $105^{\circ} \mathrm{C}$. After that concretes were treated by high temperatures $\left(200^{\circ} \mathrm{C}, 400^{\circ} \mathrm{C}, 600^{\circ} \mathrm{C}\right)$ in a muffle furnace (Fig. 1). The range of the temperatures and the course of the process are presented in Fig. 2. The specimens were stored in the object temperature over the period of one hour in order to secure the uniform heating of the concrete. In order to eliminate the detrimental effect of the rapid cooling the specimens were left to cool in the chamber of the furnace.

The determination of the leaching of heavy metals was conducted on the water extracts from concretes in accordance with the EN 12457-1-4:2002 standard [7]. 


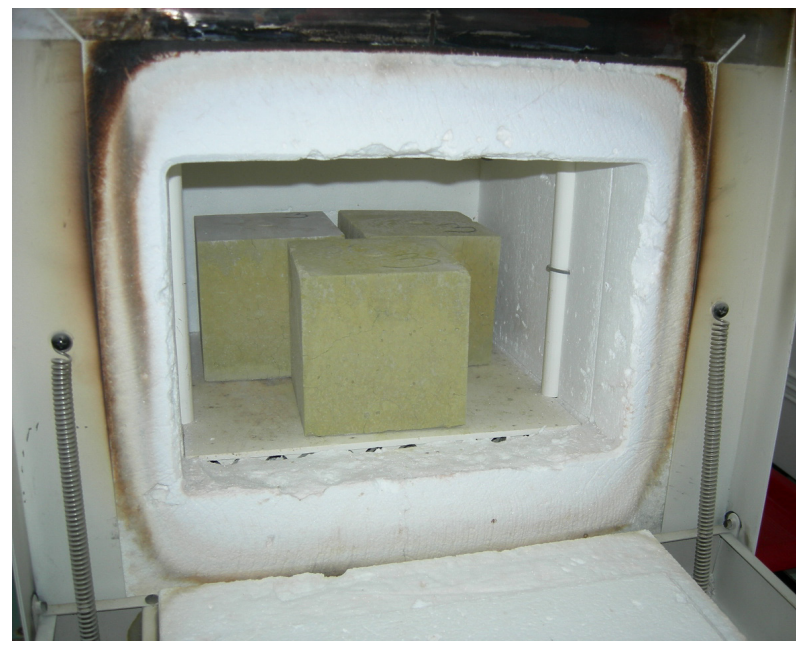

Figure 1: Concrete cubes in the muffle furnace.

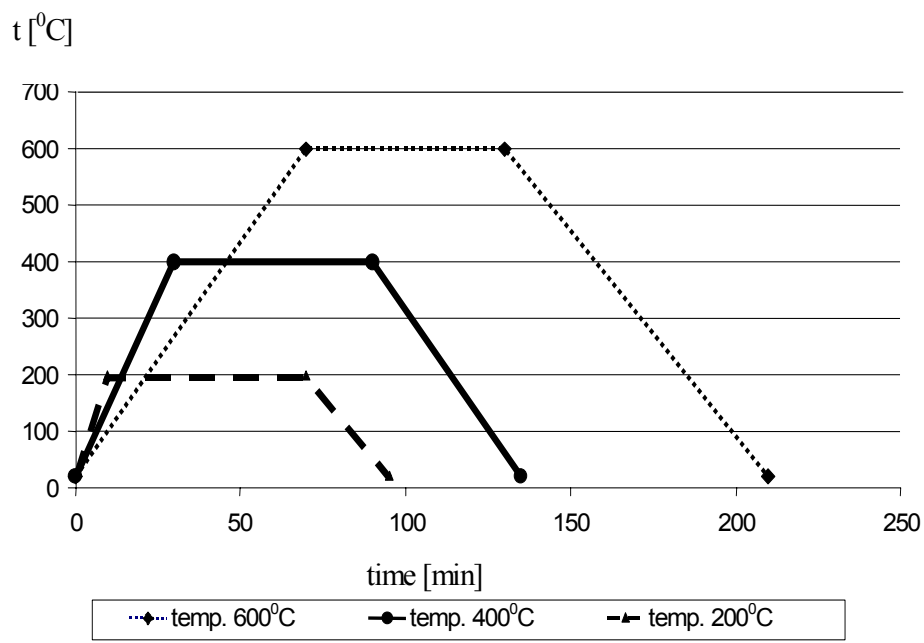

Figure 2: $\quad$ The range of the temperatures and the course of the process.

According to [7], water extracts were based on a 100 gram specimen of grinded concretes (granules with diameter smaller than $10 \mathrm{~mm}$ ). This material was leached with distilled water and simultaneously shaken over 24 hours. The weight ratio of liquid (L) to specimen mass $(\mathrm{S})$ amounts to $10(\mathrm{~L} / \mathrm{S}=10)$. Heavy metals concentrations in water eluates as well as in dry samples were determined with help of emission spectrometer ICP-AES.

The course of the examination involved the determination of the compressive strength of concrete formed into cubes containing hazardous waste to compression in accordance with standard EN 12390-3 [10]. 


\section{Results and discussion}

Concrete containing galvanic sludge stored in laboratory conditions (as presented in [9]) over the period of 28 and 90 days was subsequently ground to form particle size below $10 \mathrm{~mm}$ in diameter. After that water extracts were taken in accordance with the procedure provided for in standard [7]. Concentration of heavy metals in water extract are summarized in Table 2, with a reference to permissible concentration in surface waters of A1 category [11].

Table 2: Heavy metal leaching from grinded concretes containing galvanic sludge.

\begin{tabular}{|c|c|c|c|c|c|c|c|c|c|}
\hline \multirow[b]{2}{*}{$\begin{array}{l}\text { Concrete } \\
\text { with } \\
\text { sludge } \\
\text { on } \\
\text { cement: }\end{array}$} & \multirow{2}{*}{$\begin{array}{l}\text { Curing } \\
\text { time }\end{array}$} & \multicolumn{8}{|c|}{ Concentration of heavy metals in water extract, $\mathrm{mg} / \mathrm{l}$} \\
\hline & & $\mathrm{Cr}$ & $\mathrm{Zn}$ & $\mathrm{Ni}$ & $\mathrm{Cu}$ & $\mathrm{Cd}$ & $\mathrm{Pb}$ & As & $\mathrm{Hg}$ \\
\hline \multirow[t]{2}{*}{ CEM I } & $\begin{array}{l}28 \\
\text { days }\end{array}$ & 0.026 & 0.016 & 0.0009 & 0.0058 & 0.00003 & 0.007 & 0.0016 & 0.0001 \\
\hline & \begin{tabular}{|l|}
90 \\
days \\
\end{tabular} & 0.016 & 0.008 & 0.0009 & 0.0038 & 0.00003 & 0.006 & 0.0016 & 0.0001 \\
\hline \multirow[t]{2}{*}{$\begin{array}{l}\text { CEM } \\
\text { II/B-V }\end{array}$} & $\begin{array}{l}28 \\
\text { days }\end{array}$ & 0.025 & 0.012 & 0.0004 & 0.0063 & 0.00002 & 0.0023 & 0.0094 & 0.0001 \\
\hline & $\begin{array}{l}90 \\
\text { days }\end{array}$ & 0.014 & 0.007 & 0.0002 & 0.0033 & 0.00002 & 0.0018 & 0.0015 & 0.0001 \\
\hline \multicolumn{2}{|c|}{$\begin{array}{l}\text { Heavy metal } \\
\text { concentration } \\
{[11]^{*}}\end{array}$} & 0.05 & 3.0 & 0.05 & 0.05 & 0.005 & 0.05 & 0.05 & 0.001 \\
\hline
\end{tabular}

*Permissible value in waters with A1 category according to [11].

It is worth mentioning here that none of the values of concentrations of heavy metals in water extract from concretes used for solidification of galvanic sludge have been exceeded. In contrast, it can be stated that concrete matrices based both on Portland cement and fly ash Portland cement stabilizing galvanic sludge will form safe matrices for stabilizing matrices, road foundations will constitute matrices safe for natural environment and will not affect considerably the quality of waters in contact with them.

In accordance with the results presented in Table 2 it can be pointed out that matrices based on fly ash Portland cement in a number of cases will release much lower heavy metal $(\mathrm{Cr}, \mathrm{Zn}, \mathrm{Ni}, \mathrm{Cd}, \mathrm{Pb})$ levels than the ones based on Portland cement. The application of this cement variety for utilization of galvanic sludge results in a combined ecological effect in the form of disposal of waste (fly ash) from power industry (component of CEM II/B-V).

The amount of heavy metals leaching from concrete specimens under the influence of high temperatures was subsequently compared with the concentration of heavy metals in water extracts maturing in water over the period of 90 days (Tables 3 and 4). 
336 Waste Management and the Environment IV

Table 3: Comparison of heavy metal concentration in water extracts from CEM I 32.5 based concrete including galvanic sludge prior to and following the process of roasting.

\begin{tabular}{|c|c|c|c|c|}
\hline \multirow{2}{*}{$\begin{array}{c}\text { Heavy } \\
\text { metal }\end{array}$} & \multicolumn{4}{|c|}{$\begin{array}{c}\text { Concentration of heavy metals in water extracts from CEM I 32.5 } \\
\text { based concrete including galvanic sludge [mg/l] }\end{array}$} \\
\cline { 2 - 5 } & $200^{\circ} \mathrm{C}$ & $400^{\circ} \mathrm{C}$ & $600^{\circ} \mathrm{C}$ & $\begin{array}{c}\text { Before roasting } \\
\text { process }\end{array}$ \\
\hline $\mathrm{Zn}$ & 0.0256 & 0.032 & 0.0144 & 0.008 \\
\hline $\mathrm{Cu}$ & 0.0027 & 0.0016 & 0.0018 & 0.0038 \\
\hline $\mathrm{Pb}$ & 0.0005 & 0.0005 & 0.0006 & 0.006 \\
\hline $\mathrm{Ni}$ & 0.0006 & 0.0007 & 0.0008 & 0.0009 \\
\hline $\mathrm{Cd}$ & 0.00002 & 0.00001 & 0.00003 & 0.00003 \\
\hline $\mathrm{As}$ & 0.0016 & 0.0003 & 0.0001 & 0.0016 \\
\hline $\mathrm{Hg}$ & 0.0005 & 0.0005 & 0.0005 & 0.0001 \\
\hline $\mathrm{Cr}$ & 0.061 & 3.26 & 37.21 & 0.016 \\
\hline
\end{tabular}

Table 4: Comparison of heavy metal concentration in water extracts from CEM II/ B-V 32.5 based concrete including galvanic sludge prior to and following the process of roasting.

\begin{tabular}{|c|c|c|c|c|}
\hline \multirow{2}{*}{$\begin{array}{l}\text { Heavy } \\
\text { metal }\end{array}$} & \multicolumn{4}{|c|}{$\begin{array}{l}\text { Concentration of heavy metals in water extracts from } \\
\text { CEM II/B-V } 32.5 \text { based concrete including galvanic sludge }[\mathrm{mg} / \mathrm{l}]\end{array}$} \\
\hline & $200^{\circ} \mathrm{C}$ & $400^{\circ} \mathrm{C}$ & $600^{\circ} \mathrm{C}$ & $\begin{array}{l}\text { Before roasting } \\
\text { process }\end{array}$ \\
\hline $\mathrm{Zn}$ & 0.0116 & 0.007 & 0.0052 & 0.007 \\
\hline $\mathrm{Cu}$ & 0.0062 & 0.0048 & 0.0027 & 0.0033 \\
\hline $\mathrm{Pb}$ & 0.00012 & 0.0001 & 0.00008 & 0.0018 \\
\hline $\mathrm{Ni}$ & 0.00043 & 0.00024 & 0.00035 & 0.0002 \\
\hline $\mathrm{Cd}$ & 0.00006 & 0.00002 & 0.00003 & 0.00002 \\
\hline As & 0.0023 & 0.0265 & 0.0030 & 0.0015 \\
\hline $\mathrm{Hg}$ & 0.00041 & 0.00037 & 0.00041 & 0.0001 \\
\hline $\mathrm{Cr}$ & 0.067 & 9.19 & 72.20 & 0.014 \\
\hline
\end{tabular}

The analysis of the concentration of heavy metals in water extracts from concretes containing hazardous waste gives foundation to the statement that in a majority of cases the rise in temperature does not result in the rise of the release of heavy metals into the surrounding environment. The results of $\mathrm{Zn}, \mathrm{Cu}, \mathrm{Pb}, \mathrm{Ni}$, $\mathrm{Cd}$ and As element leaching from concretes exposed to high temperature virtually indicate the same degree of heavy metal leaching as for the case of concretes which were not subjected to high temperature. However, for the case of chromium the results show a rise in this metal leaching along with the increase in the temperature of roasting. The highest concentration of chromium was registered for water extract for the case of concrete exposed to $600^{\circ} \mathrm{C}$. 
The low chromium concentration in the water extract, which was not subjected to high temperature, may be associated with the fact that both the overall porosity and total volume of air pores decreases as a result of reaction of hydratation [2]. The other factor responsible for the low chromium concentration in the water extracts for the sample stored in laboratory is associated with the impact structure of the concrete. In the samples exposed to high temperature the water of crystallization disappears, which promotes the slow process of the destruction of concrete structure. Along with it, new surfaces start to be exposed to external media (including leaching water) [12]. This process results in the increase of the amount of chromium released into the environment. The surface of the examined specimens exposed to high temperature displays numerous cracks and green-yellowish coating, which is the evidence of the mobility of chromium. However, it is worth noting that the lower level of chromium leaching was gained for the case of stabilizing galvanic sludge based on Portland cement (roasting to $600^{\circ} \mathrm{C}$ was followed with the reading of $37.21 \mathrm{mg} / \mathrm{l}$ concentration) for the case of concrete based on CEM II/B-V cement (after roasting at $600^{\circ} \mathrm{C}$ the concentration of chromium amounted $72.20 \mathrm{mg} / \mathrm{l}$ ).

Besides, this study shows that the concentration of mercury in the examined water extracts from concrete decreases along with an increase in the temperature. This is associated with the volatility of mercury. Hence, the concentration of mercury in water extracts subjected to high temperature is lower than for the case of specimens stored in the laboratory.

Concrete specimens containing galvanic sludge formed into cubes with dimensions of $10 \times 10 \times 10 \mathrm{~cm}$ were subjected to compression testing in order to determine the strength of the formed concrete. The resistance to compression was determined after the period of 90 day of specimen storage in laboratory and after roasting them at the temperatures of $200^{\circ} \mathrm{C}, 400^{\circ} \mathrm{C}$ and $600^{\circ} \mathrm{C}$. The results are summarized in Fig. 3.

The results in Fig. 3 indicate that the concrete solidifying waste tends to lose its strength after exposition to high temperature along with the rise in the temperature of roasting. Moreover, concrete demonstrates lower strength in comparison to the specimens stored in the laboratory. However, higher resistance to compression was registered for the case of concrete specimens based on CEM II/B-V cement than for the case of concrete based on the Portland cement.

The phenomenon that is beneficial is associated with the maintenance of strength by the concrete even after the exposing it to the temperature in the range of $600^{\circ} \mathrm{C}$. The conclusion from this is that concrete matrices used for solidification of galvanic sludge preserve their properties after the exposition to ultimate conditions.

\section{Conclusions}

The testing conducted by this author concerning the effect of high temperature on heavy metal leaching from concretes containing galvanic sludge allow the statement of the following conclusions: 


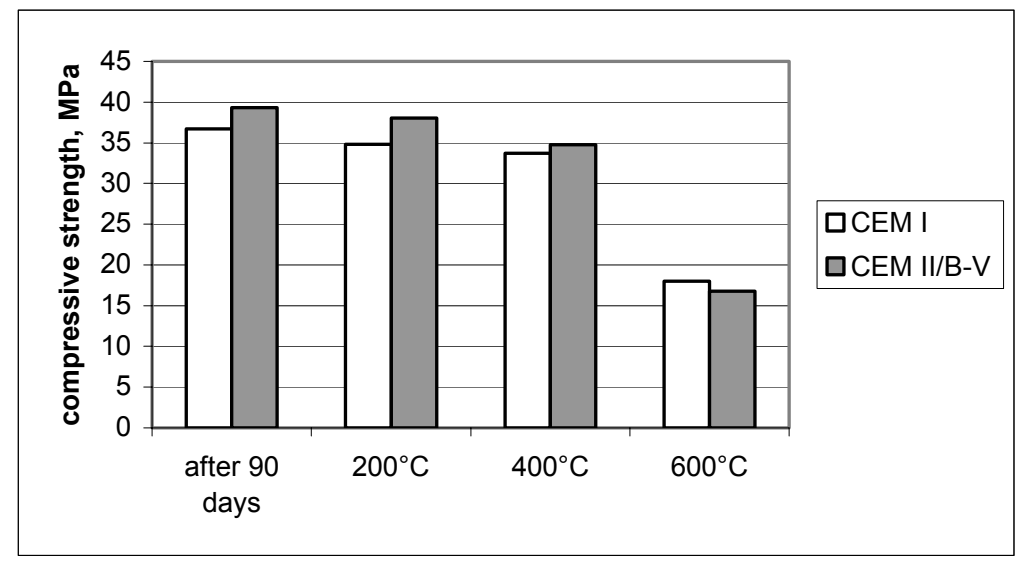

Figure 3: Compressive strength of concretes with the addition of galvanic sludge after the influence of high temperatures.

1. The leaching of a majority of heavy metals is low, which means that the hazard associated with the contamination of the environment with heavy metal migration from hazardous waste is small.

2. Following a rise in temperature the concentration of mercury in water extracts from concrete decreases, which is connected with the volatility of this element.

3. A rise in temperature successively promotes the leaching of chromium into the surrounding environment.

4. For the case of chromium lower leaching was registered in concrete specimens based on Portland cement solidifying galvanic sludge after subjecting it to high temperature.

5. Concrete containing galvanic sludge based on Portland cement with fly ash constituent demonstrates bigger resistance to compression than concrete based on CEM I $32.5 \mathrm{R}$ both after storing it in laboratory and after exposition to high temperature.

\section{Acknowledgement}

The current research was financially supported from a research project by the Ministry of Science and High Education, no. PB-1493/T02/2006/30.

\section{References}

[1] EN 197-1:2002/A1:2005 Cement -Part 1: Composition, specifications and conformity criteria for common cements.

[2] Batchelor, B., Overview of waste stabilization with cement, Waste Management, 26, pp. 689-698, 2006. 
[3] Król, A., Immobilization of heavy metals in composites based on binders with high content of mineral additives. Ninth CANMET/ACI International Conference on Fly Ash, Silica Fume, Slag and Natural Pozzolans in Concrete. Warsaw, pp. 265-282, 2007.

[4] Sakr, K., El-Hakim, E., Effect of high temperature or fire on heavy weight concrete properties. Cement and Concrete Research, 35, pp. 590-596, 2005.

[5] Decree of Minister of the Environment, September, $27^{\text {th }} 2001$ regarding catalogue of waste materials. Journal of Laws No 112, item 1206.

[6] Council Decision (2003/33/EC) of 19 December 2002 establishing criteria and procedures for the acceptance of waste at landfills pursuant to Article 16 of and Annex II to Directive 1999/31/EC

[7] EN 12457-1-4:2002 Characterization of waste - Leaching - Compliance test for leaching of granular waste materials and sludges - Part 4: One stage batch at a liquid to solid ratio of $10 \mathrm{l} / \mathrm{kg}$ for materials with particle size below $10 \mathrm{~mm}$ (without or with size reduction).

[8] EN 206-1: 2000 Concrete - Part 1: Specification, performance, production and conformity.

[9] EN 12390-2: 2001, Testing hardened concrete - Part 2: Making and curing specimens for strength tests

[10] EN 12390-3: 2001, Testing hardened concrete - Part 3: Compressive strength of test specimens

[11] Decree of Minister of the Environment, November, $27^{\text {th }} 2002$ with regard to requirements for surface waters used for supply of population with drinking water. Journal of Laws no. 204/2002, item 1728

[12] Lion, M., Skoczylas, F., Lafhaj, Z., Sersar, M., Experimental study on a mortar. Temperature effects on porosity and permeability. Residual properties or direct measurements under temperature, Cement and Concrete Research, 35, pp. 1937-1942, 2005. 